Article

\title{
Effect of SOP "STAR COW" on Enteric Gaseous Emissions and Dairy Cattle Performance
}

\author{
Elizabeth G. Ross ${ }^{1}$, Carlyn B. Peterson ${ }^{1}$, Angelica V. Carrazco ${ }^{1}$, Samantha J. Werth ${ }^{1}$, \\ Yongjing Zhao ${ }^{2}$, Yuee Pan ${ }^{1}$, Edward J. DePeters ${ }^{1}$, James G. Fadel ${ }^{1}$, Marcello E. Chiodini ${ }^{3}$, \\ Lorenzo Poggianella ${ }^{4}$ and Frank M. Mitloehner ${ }^{1, *(D)}$ \\ 1 Department of Animal Science, University of California, Davis, Davis, CA 95616-8521, USA; \\ eghumphreys@ucdavis.edu (E.G.R.); cbpeterson@ucdavis.edu (C.B.P.); acarrazco@ucdavis.edu (A.V.C.); \\ sjwerth@ucdavis.edu (S.J.W.); yepan@ucdavis.edu (Y.P.); ejdepeters@ucdavis.edu (E.J.D.); \\ jgfadel@ucdavis.edu (J.G.F.) \\ 2 Air Quality Research Center, University of California, Davis, Davis, CA 95616-8521, USA; \\ yjzhao@ucdavis.edu \\ 3 Department of Agricultural and Environmental Sciences (DiSAA), University of Milan, \\ Via Festa del Perdono, 7, 20122 Milano MI, Italy; marcello.chiodini@guest.unimi.it \\ 4 Department of Land, Air and Water Resources, University of California, Davis, Davis, CA 95616-8521, USA; \\ lpoggianella@ucdavis.edu \\ * Correspondence: fmmitloehner@ucdavis.edu
}

Received: 13 October 2020; Accepted: 4 December 2020; Published: 8 December 2020

check for updates

\begin{abstract}
Feed additives have received increasing attention as a viable means to reduce enteric emissions from ruminants, which contribute to total anthropogenic methane (CH4) emissions. The aim of this study was to investigate the efficacy of the commercial feed additive SOP STAR COW (SOP) to reduce enteric emissions from dairy cows and to assess potential impacts on milk production. Twenty cows were blocked by parity and days in milk and randomly assigned to one of two treatment groups $(n=10)$ : supplemented with $8 \mathrm{~g}$ /day SOP STAR COW, and an unsupplemented control group. Enteric emissions were measured in individual head chambers over a 12-h period, every 14 days for six weeks. SOP-treated cows over time showed a reduction in CH4 of $20.4 \%$ from day 14 to day $42(p=0.014)$, while protein $\%$ of the milk was increased $(+4.9 \%$ from day 0 to day $14(p=0.036)$ and $+6.5 \%$ from day 0 to day $42(p=0.002)$ ). However, $\mathrm{kg}$ of milk protein remained similar within the SOP-treated cows over the trial period. The control and SOP-treated cows showed similar results for $\mathrm{kg}$ of milk fat and $\mathrm{kg}$ of milk protein produced per day. No differences in enteric emissions or milk parameters were detected between the control and SOP-treated cows on respective test days.
\end{abstract}

Keywords: feed additive; methane mitigation; enteric emissions; greenhouse gas; climate change

\section{Introduction}

Animal-sourced foods (ASF) have been under increased scrutiny due to public awareness and concern over environmental impacts. Animals are vital in many regions of the world and represent the foundation of the human food system. Animal-sourced foods can also improve national agricultural alignment to several UN Sustainable Development Goals by providing nutritious food to the population and stable livelihoods for rural communities [1], where the lack of arable land makes it possible only for ruminants to convert non-edible plants into food.

Nevertheless, the agricultural livestock sector (i.e., ASF) has been identified for its contributions to greenhouse gas (GHG) production. According to the Intergovernmental Panel on Climate Change (IPCC) [2], agriculture contributes 10 to $12 \%$ of anthropogenic $\mathrm{CO}_{2}, 40 \%$ of methane $\left(\mathrm{CH}_{4}\right)$, and $60 \%$ of nitrous oxide $\left(\mathrm{N}_{2} \mathrm{O}\right)$ emissions. Methane and $\mathrm{N}_{2} \mathrm{O}$ are the most significant greenhouse gases produced 
by livestock production. While $\mathrm{N}_{2} \mathrm{O}$ originates mainly from nitrogen $(\mathrm{N})$ fertilizers and manure application to agricultural soils [3], $\mathrm{CH}_{4}$ comes from enteric fermentation in ruminants [2] and manure decomposition during storage.

In the United States, the livestock sector is estimated to contribute $35 \%$ of the anthropogenic $\mathrm{CH}_{4}, 72 \%$ of which originates from enteric fermentation and $28 \%$ from manure management [4]. In California, where 19\% of US milk is produced [5], the California Air Resource Board inventory estimated that the dairy sector is responsible for $55 \%$ of anthropogenic $\mathrm{CH}_{4}$ emissions, $45 \%$ of which come from enteric fermentation [6].

In rumen, feedstuffs are digested and converted through the process of microbial fermentation primarily into volatile fatty acids (VFA), including propionate, butyrate, and acetate. Methane is also produced via archaea present in the rumen. Methane constitutes a loss of approximately $5.8 \%$ of dietary gross energy intake for U.S. dairy cattle [7]. Energy loss in the form of $\mathrm{CH}_{4}$ as well as the environmental impacts associated with enteric $\mathrm{CH}_{4}$ production give rise to a need for $\mathrm{CH}_{4}$ mitigation strategies in dairy production. Finding economically feasible options for dairy producers to reduce emissions is paramount because California Senate Bill 1383 requires a reduction in $\mathrm{CH}_{4}$ emissions from California dairies by 40\% from 2013 levels by 2030. California is the first state with a methane mitigation law and is setting the standard for how this reduction can be achieved in the U.S. and throughout other regions in the world.

Several enteric $\mathrm{CH}_{4}$ mitigation strategies for dairy cattle have been investigated, including: $\mathrm{CH}_{4}$ inhibitors such as bromochloromethane [8,9] and 3-Nitrooxypropanol [10]; electron receptors (e.g., nitrate [11]); ionophores (e.g., monensin [9]); and plant bioactive compounds such as tannins [12], essential oils [13], and bromoform found in certain seaweeds [14]. Although some of these strategies have shown promising mitigation potential, they have also manifested issues, including toxicity to the animal or the environment, short-term effects due to rumen adaptation, inconsistent results, or a negative effect on production.

SOP SQC233-005A-SQE034 (commercial name: SOP ${ }^{\circledR}$ STAR COW; SOP Srl, VA, Italy) is a feed additive containing minerals, deactivated yeast, condensed tannins from carob flour, and bentonite clay. SOP STAR COW (SOP) is processed using proprietary technology with the aim of improving feed efficiency and reducing production of $\mathrm{CH}_{4}$, and its subsequent eructation, resulting in reduced energy loss. SOP STAR COW has been commercially available for several years and its individual components are widely used and commercialized. Over a year testing period, SOP was found to increase milk yield on seven commercial dairy farms in Italy [15]. SOP has not been previously studied for the efficacy of reducing enteric $\mathrm{CH}_{4}$ production from lactating dairy cows. This study aims to evaluate the efficacy of the feed additive SOP on enteric gaseous emissions and the impact on milk production from lactating dairy cows. It was hypothesized, given the combination of ingredients included in SOP and the previous in vivo work conducted for milk production, that when fed to lactating dairy cows SOP will reduce $\mathrm{CH}_{4}$ emissions and improve milk production.

\section{Materials and Methods}

\subsection{Study Design}

This study was conducted at the UC Davis Dairy Teaching and Research facility (Davis, CA, USA) with the approval of the Institutional Animal Care and Use Committee, protocol number 20601. Twenty lactating Holstein dairy cows in mid to late lactation (DIM $=153 \pm 17$ ) were randomly assigned to one of two treatment groups: treatment (SOP) or control, with 10 cows per group $(n=10)$. The study was arranged as a randomized complete block design with cows blocked by parity and days in milk. Within each treatment group, half of the animals were first lactation cows and the other half were multiparous animals either in their second or third lactation, to be representative of a typical commercial dairy operation in California. 
Animals were fed an industry-standard total mixed ration (TMR) containing corn silage as the main forage component (Table 1). Diets were formulated to contain approximately $17 \%$ crude protein. Corn silage was sampled daily for dry matter (DM) with the SCiO, a handheld micro spectrometer (Consumer Physics, Inc; St. Cloud, Minnesota) to determine the correct inclusion amount for the TMR, in addition to weekly DM samples that were collected. Feed samples were dried in an oven at $100{ }^{\circ} \mathrm{C}$ for $14 \mathrm{~h}$ in triplicate and averaged to determine DM. All cows were adapted to the basal control diet without SOP supplementation for 14 days prior to the beginning of treatments (acclimation period, day -14 to day 0 ). At the end of the acclimation period, cows were fed either the control diet or the SOP treatment diet. Treatment was supplemented for a 42-day period, with the first 14 days per each cow considered as an acclimation period to the SOP feed.

Table 1. Ingredients of basal total mixed ration on an as fed and dry matter basis $(\mathrm{kg} / \mathrm{d} / \mathrm{cow})$.

\begin{tabular}{|c|c|c|}
\hline Feed Ingredients & As Fed (kg/cow Daily) & Dry Matter Basis (kg/cow Daily) $^{1}$ \\
\hline Corn Silage & 21.97 & 6.15 \\
\hline Corn, Steam Flaked & 4.08 & 3.58 \\
\hline Soybean Meal & 3.36 & 2.99 \\
\hline Alfalfa Hay & 2.72 & 2.42 \\
\hline Almond Hulls & 2.51 & 2.26 \\
\hline Cottonseed, Linted & 1.99 & 1.84 \\
\hline Soybean Hulls & 1.36 & 1.24 \\
\hline Mineral $^{2}$ & 0.39 & 0.38 \\
\hline EnerGII 3 & 0.27 & 0.26 \\
\hline Strata 4 & 0.09 & 0.09 \\
\hline Limestone, Ground & 0.09 & 0.09 \\
\hline
\end{tabular}

${ }^{1}$ The diet was formulated using a linear program for an average milk yield of $36.5 \mathrm{~kg}$ daily at $3.6 \%$ milk fat that assumed an intake of $21.3 \mathrm{~kg}$ DM daily of the formulated diet. ${ }^{2}$ Custom mineral mix containing: calcium, $12.56 \%$; phosphorus, 5.33\%; magnesium, 4.3\%; sulfur, 2.17\%; iron, 1985.36 ppm; manganese, 2664.5 ppm; zinc, 4519.78 ppm; copper, 668.8 ppm; iodine, 58.54 ppm; cobalt, 25.06 ppm; selenium, 22.79 ppm; vitamin A, $553.00 \mathrm{KIU} / \mathrm{kg}$; vitamin D, $185.19 \mathrm{KIU} / \mathrm{kg}$; vitamin E, $4188.79 \mathrm{IU} / \mathrm{kg}$; biotin $58.80 \mathrm{mg} / \mathrm{kg}$; sodium bicarb, 33.33\%; magnesium oxide, 7.14\%; Ethylenediamine dihydroiodide, $29.34 \mathrm{mg} / \mathrm{kg}$; yeast, $29.32 \mathrm{BCFU} / \mathrm{kg}$; diflubenzuron, $0.0197 \%$; Zinpro 120, 0.88\% (Nutrius, Kingsburg, CA). ${ }^{3}$ A calcium salt of fatty acids containing $50 \%$ palmitic and $35 \%$ oleic fatty acids (Virtus Nutrition, Corcoran, CA, USA). ${ }^{4}$ A calcium salt of fatty acids containing a blend of palmitic, stearic, and oleic fatty acids with a $16 \%$ eicosapentaenoic acid (EPA)/docosahexaenoic acid (DHA) omega-3 fatty acids (Virtus Nutrition, Corcoran, CA, USA).

The SOP additive was mixed with ground corn and fed as a top dress to deliver a total of $8 \mathrm{~g}$ of SOP fed per cow per day, according to the manufacturer's specifications. The treatment cow top dress included $92 \mathrm{~g}$ of ground corn mixed with $8 \mathrm{~g}$ of SOP, for a total $100 \mathrm{~g}$ of top dress per day. Control cows received a total of $100 \mathrm{~g}$ of ground corn as a top dress daily. Animals received $67 \mathrm{~g}$ of the top dress at the morning feeding and $33 \mathrm{~g}$ of the top dress in the evening, as the morning intake contained, on average, $2 / 3$ of the cows' daily feed. Cows were individually fed their respective diets using the Calan Broadbent Feeding System (Calan gate; American Calan, Northwood, NH, USA).

Prior to the acclimation phase, each cow was trained to use their respective Calan gate. Feed was administered twice daily after the morning and evening milkings and diets were offered on an ad libitum basis, with a target of $5 \%$ daily feed refusals. Refusals were weighed before each morning feeding and sampled for DM analysis to determine daily dry matter intake (DMI). Weekly feed samples of corn silage and TMR were collected and analyzed for chemical composition and DM to ensure correct diet formulation. Chemical composition was determined by proximate analysis conducted by Denele Analytical, Inc (Woodland, CA). Dry matter was determined by drying samples in triplicate in an oven for $14 \mathrm{~h}$ at $100{ }^{\circ} \mathrm{C}$ and averaging the three sub samples. The feeding schedule and treatment periods for the cows were staggered to allow for gaseous emission sampling of two cows per day (one control and one treatment) in the head chamber system, with animal pairs randomly assigned to their respective treatment start time. 


\subsection{Emissions Measurements}

Enteric emission measurements were collected using head chambers (HC). Both chamber construction and sampling procedures were based on the work of Place et al. (2011) [16]. Each head chamber was $151 \mathrm{~cm} \times 104 \mathrm{~cm} \times 76.2 \mathrm{~cm}(\mathrm{H} \times \mathrm{W} \times \mathrm{D})$ with polycarbonate sheeting on all sides to allow a full view of the cows during the enteric emission data collection. The chambers were equipped with head hoods specially made from Cordura waterproof fabric (Cordura Advanced Fabrics, USA) to fit the chamber opening and secure around the animal's neck. A vacuum was attached to the HC to pull air from inside the chamber and pump it outside the chamber (Peerless Blowers, Hot Springs, North Carolina, USA). Cattle were secured in the head chamber using quick-release neck chains. Emissions were collected over a 12-h period (approximately 0600 to $1800 \mathrm{~h}$ ) and animals were sampled at 14-day intervals. HC sampling occurred on each cow's respective days $0,14,28$, and 42.

The HC sampling system has the advantage of allowing continuous enteric emission data collection over an extended time period (12-h in the current study) and therefore reduces the cow-to-cow variability, which would be lost with shorter measurement periods. Eructated emissions were analyzed for $\mathrm{CH}_{4}$, $\mathrm{CO}_{2}, \mathrm{~N}_{2} \mathrm{O}$, and $\mathrm{NH}_{3}$.

Gas samples were measured in rounds of $15 \mathrm{~min}$ from each chamber, followed by a 15-min ambient air sampling period to correct chamber emissions from ambient emissions, for $12 \mathrm{~h}$. Gas samples were collected in a mobile trailer that housed an Innova 1412 photo-acoustic multi-gas analyzer (LumaSense Technologies Inc., Ballerup, Denmark), a computer, and other support equipment. A full list of gases analyzed and their respective detection ranges are reported in Table 2.

Table 2. Gases analyzed, detection limits, and detection ranges used to measure emissions from heads chambers.

\begin{tabular}{ccc}
\hline Gases & Detection Limits $(\mu \mathrm{g} / \mathrm{L})$ & Upper Range $(\mathrm{g} / \mathrm{L})$ \\
\hline $\mathrm{CO}_{2}$ & 2.75 & 1.83 \\
$\mathrm{NH}_{3}$ & 0.71 & 0.71 \\
$\mathrm{CH}_{4}$ & 0.06 & 0.57 \\
$\mathrm{~N}_{2} \mathrm{O}$ & 0.05 & 1.83 \\
\hline
\end{tabular}

\subsection{Milk Sampling}

Cows were milked immediately before entering and after exiting the head chambers and had ad libitum access to their respective diet and water for the 12-h sampling period. Milk yields were collected at each milking for all animals. Milk samples were collected every 14-days and analyzed for fat, true protein, milk urea nitrogen (MUN), and solids-not-fat (SNF). Samples were sent to Central Counties DHIA (Atwater, CA, USA) for analysis and used to establish treatment period averages for ECM.

\subsection{Calculations}

\subsubsection{Emissions Calculations}

Data regarding the concentrations of the outlet air samples from the heads chamber over each 15-min period were truncated to remove the first five minutes and last two minutes of the sample to prevent carry-over effects. The following equation was used to calculate the emission rate in $\mathrm{mg} / \mathrm{h} / \mathrm{head}$ of gases from the head chambers:

$$
\text { Emission Rate }(\mathrm{mg} / \mathrm{h} / \mathrm{head})=\{[(\mathrm{MIX}) \times(\mathrm{FL}) \times(60)] / \mathrm{MV}\} \times(\mathrm{MW}) \times(\mathrm{Conv}) / \mathrm{Head}
$$

where MIX is the net concentration (inlet concentration-outlet concentration) in either ppm (parts per million) or $\mathrm{ppb}$ (parts per billion), FL is the continuous ventilation rate of the head chambers (2300-2500 L/min), 60 is the conversion from minute to hour, MV is the volume of one molar gas and equals to 24.04 (liter/mole) at temperature $20^{\circ} \mathrm{C}$ and one atmosphere pressure, MW is the molecular 
weight of the gas in grams per mole, and Conv is a conversion factor of $10^{-3}$ for concentration in ppm and $10^{-6}$ for concentration in ppb. Head is the number of animals in the head chamber. In this experiment, Head $=1$.

\subsubsection{Energy-Corrected Milk}

Energy-corrected milk (ECM) values were an average ECM for each two-week interval during the treatment period and calculated as follows [17]:

$$
(0.327 \times \text { Milk Yield }(\mathrm{kg}))+(12.95 \times \text { Fat }(\mathrm{kg}))+(7.2 \times \text { Protein }(\mathrm{kg}))
$$

Energy-corrected milk values were established for the AM and PM milkings. To establish a 24-h ECM, the AM and PM values were added together and averaged over a two-week period.

\subsubsection{Corrected Dry Matter Intake}

The corrected dry matter intake equation was developed from data reported in van Lingen et al. (2017), showing that approximately $25 \%$ of the $\mathrm{CH}_{4}$ being produced from dairy cattle at any given time is coming from the previous $24 \mathrm{~h}$ DMI [18]. The following equation therefore accounts for the contribution of $\mathrm{CH}_{4}$ coming from the previous day's intake:

$$
\operatorname{cDMI}(\mathrm{kg})=0.25 \times \text { DMI }(\text { previous days feed }(\mathrm{kg}))+0.75 \times \text { DMI }(\text { in head chamber }(\mathrm{kg}))
$$

\subsection{Data Analysis}

All data were analyzed using the lmerTest package in R [19]. Least square means (LSM) and contrast between treatment by day $p$-values were determined using the emmeans package in $R$ [20]. Pairwise comparisons of treatment by day interaction LSM were determined by a Tukey test using the multcompView package in R [21]. Differences were declared significant at $p \leq 0.05$ and showed a trend at $0.05<p \leq 0.10$. $p$-values reported in the tables are from the ANOVA table while $p$-values reported in the text are from pairwise comparisons of the interaction. The model used to evaluate emissions data is:

$$
Y_{i j k l}=\mu+C_{i}+T_{j}+D_{k}+P_{l}+T_{j}: D_{k}+e_{i j k l}
$$

where $Y_{i j k l}$ is the dependent variable for the ith cow in the jth treatment on the kth test day $(0,14,28$, 42 ) and in the lth parity. $\mu$ is the overall mean, $C_{i}$ is the experimental unit (cow), $T_{j}$ is the treatment, $D_{k}$ is the test day $(0,14,28,42), P_{l}$ is the parity of the cow, $T_{j}: D_{k}$ is the interaction between treatment and test day, and $e_{i j k l}$ is the error term associated with the model $\sim \mathrm{N}\left(0, \sigma_{\mathrm{e}}{ }^{2}\right)$. Days in milk was initially included in the model as a continuous variable and was removed as it was not significant. Parity was included in the model as a categorical variable. Cow was a random effect, with all other variables as fixed effects.

\section{Results}

\subsection{Enteric GHG Emissions}

Table 3 shows uncorrected gas emissions for animals in the head chambers. No differences for $\mathrm{CH}_{4}, \mathrm{CO}_{2}, \mathrm{~N}_{2} \mathrm{O}$, and $\mathrm{NH}_{3}$ were detected between SOP-treated cows and control cows on respective treatment days. The analysis of $\mathrm{CH}_{4}$ data showed that the emissions from within the SOP group had a significant decrease from day 14 to day 42 with a reduction of $20.4 \%$ (Table $3 ; p=0.014$ ). While the emissions from within the control group did not show significant differences over time there was still approximately a $10 \%$ reduction from day 14 to 42 (Table 3). Additionally, there was no significant differences for $\mathrm{CH}_{4}$ seen from day 0 (prior to treatment administration) to days 14 or 42 within the SOP treatment or the control groups, meaning $\mathrm{CH}_{4}$ emissions before SOP treatment administration were similar to $\mathrm{CH}_{4}$ emissions after 14 and 42 days of treatment. Carbon dioxide emissions, within the 
SOP-treated cows showed a decrease from day 14 to day $42(-18.4 \%, p=0.011)$, while the emissions from within the control group fluctuated without significant variations throughout the test days (Table 3). The $\mathrm{N}_{2} \mathrm{O}$ emissions within both the control and within the SOP group increased when compared with day 0 . After the SOP STAR COW supplementation, the SOP group did not show significant variations, while the control group emitted significantly $(p<0.016)$ larger amounts of $\mathrm{N}_{2} \mathrm{O}$ at day 28 compared with day $14(+40.6 \%$; Table 3$)$. Ammonia emissions decreased greatly for both SOP-treated cows and control cows after the initial measurements (day 0 of trial period; Table 3 ).

Table 3. Gaseous emissions from head chambers for control and treatment groups $(n=10)$ on days 0 , 14,28 , and 42 with least square means, pooled standard errors (SEM), and $p$-values. Measured gases include methane, carbon dioxide, nitrous oxide, and ammonia.

\begin{tabular}{|c|c|c|c|c|c|c|c|c|c|c|c|c|}
\hline \multirow{3}{*}{ Trait } & \multicolumn{8}{|c|}{ LSM } & \multirow{3}{*}{ SEM } & \multicolumn{3}{|c|}{$p$-Value } \\
\hline & $\mathrm{C}$ & SOP & $\mathrm{C}$ & SOP & C & SOP & $\mathrm{C}$ & SOP & & \multirow{2}{*}{ Trt } & \multirow{2}{*}{ Day } & \multirow{2}{*}{ Trt:Day } \\
\hline & \multicolumn{2}{|c|}{ do } & \multicolumn{2}{|c|}{ d14 } & \multicolumn{2}{|c|}{ d28 } & \multicolumn{2}{|c|}{ d42 } & & & & \\
\hline $\mathrm{CH}_{4}(\mathrm{~g} / \mathrm{h})$ & $24.70^{\mathrm{ab}}$ & $21.87^{\mathrm{ab}}$ & $24.04^{\mathrm{ab}}$ & $25.10^{\mathrm{b}}$ & $23.71^{\mathrm{ab}}$ & $24.73^{b}$ & $21.59^{a b}$ & $19.98^{\mathrm{a}}$ & 1.14 & 0.55 & $<0.001$ & 0.014 \\
\hline $\mathrm{CO}_{2}(\mathrm{~g} / \mathrm{h})$ & $718^{\mathrm{abc}}$ & $659^{a b c}$ & $672^{\mathrm{abc}}$ & $713^{b c}$ & $675^{\mathrm{abc}}$ & $728^{c}$ & $593^{a b}$ & $582^{\mathrm{a}}$ & 29.93 & 0.81 & $<0.001$ & 0.041 \\
\hline $\mathrm{N}_{2} \mathrm{O}(\mathrm{mg} / \mathrm{h})$ & $12.69^{\mathrm{ab}}$ & $11.38^{\mathrm{a}}$ & $18.00^{\mathrm{bc}}$ & $24.45^{\mathrm{cd}}$ & $25.31^{\mathrm{d}}$ & $28.54^{\mathrm{d}}$ & $28.43^{\mathrm{d}}$ & $27.71^{\mathrm{d}}$ & 1.62 & 0.065 & $<0.001$ & 0.033 \\
\hline $\mathrm{NH}_{3}(\mathrm{mg} / \mathrm{h})$ & $21.32^{b}$ & $21.51^{b}$ & $5.93^{\mathrm{a}}$ & $5.99^{\mathrm{a}}$ & $4.78^{\mathrm{a}}$ & $5.15^{\mathrm{a}}$ & $2.72^{\mathrm{a}}$ & $1.83^{\mathrm{a}}$ & 1.47 & 0.94 & $<0.001$ & 0.96 \\
\hline
\end{tabular}

Table 4 reports gaseous emissions standardized for DMI while animals were housed in head chambers. No differences for $\mathrm{CH}_{4}, \mathrm{CO}_{2}, \mathrm{~N}_{2} \mathrm{O}$, and $\mathrm{NH}_{3}$ were detected between SOP-treated cows and control cows on respective treatment days. The reduction seen for $\mathrm{CH}_{4}$ in uncorrected emissions from day 14 to 42 for SOP was not seen when corrected for DMI. However, the control group does show a reduction in DMI standardized $\mathrm{CH}_{4}$ emissions from day 0 to day $42(p=0.003)$, while no reduction is seen in the treatment group. A similar reduction is seen for $\mathrm{CO}_{2}$ from day 0 to $42(p=0.001)$.

Table 4. Gaseous emissions corrected for dry matter intake (DMI) from head chambers (12 h period) for control and treatment groups $(n=10)$ on days $0,14,28$, and 42 with least square means, pooled standard errors (SEM), and $p$-values. Emission measurements reported are on a per cow basis in either mg or $\mathrm{g} / \mathrm{h} / \mathrm{kg}$ DMI.

\begin{tabular}{|c|c|c|c|c|c|c|c|c|c|c|c|c|}
\hline \multirow{3}{*}{ Trait } & \multicolumn{8}{|c|}{ LSM } & \multirow{3}{*}{ SEM } & \multicolumn{3}{|c|}{$p$-Value } \\
\hline & $\mathrm{C}$ & SOP & C & SOP & C & SOP & C & SOP & & \multirow{2}{*}{ Trt } & \multirow{2}{*}{ Day } & \multirow{2}{*}{ Trt:Day } \\
\hline & \multicolumn{2}{|c|}{ do } & \multicolumn{2}{|c|}{ d14 } & \multicolumn{2}{|c|}{ d28 } & \multicolumn{2}{|c|}{ d42 } & & & & \\
\hline $\mathrm{CH}_{4}(\mathrm{~g} / \mathrm{h} / \mathrm{kg} \mathrm{DMI})$ & $1.90^{c}$ & $1.63^{\mathrm{abc}}$ & $1.61^{\mathrm{abc}}$ & $1.73^{\mathrm{bc}}$ & $1.43^{\mathrm{ab}}$ & $1.63^{\mathrm{abc}}$ & $1.28^{\mathrm{a}}$ & $1.37^{\mathrm{ab}}$ & 0.10 & 0.64 & $<0.01$ & 0.027 \\
\hline $\mathrm{CO}_{2}(\mathrm{~g} / \mathrm{h} / \mathrm{kg} \mathrm{DMI})$ & $55.37^{c}$ & $49.15^{\mathrm{abc}}$ & $45.08^{\mathrm{abc}}$ & $50.99^{\mathrm{bc}}$ & $39.36^{\mathrm{ab}}$ & $48.25^{\mathrm{bc}}$ & $35.27^{\mathrm{a}}$ & $40.00^{\mathrm{abc}}$ & 3.22 & 0.17 & $<0.01$ & 0.020 \\
\hline $\mathrm{N}_{2} \mathrm{O}(\mathrm{mg} / \mathrm{h} / \mathrm{kg}$ DMI $)$ & $1.02^{\mathrm{ab}}$ & $0.84^{\mathrm{a}}$ & $1.19^{\mathrm{ab}}$ & $1.42^{\mathrm{abc}}$ & $1.55^{\mathrm{bc}}$ & $1.90^{c}$ & $1.74^{\mathrm{bc}}$ & $2.08^{c}$ & 0.16 & 0.067 & $<0.001$ & 0.22 \\
\hline $\mathrm{NH}_{3}(\mathrm{mg} / \mathrm{h} / \mathrm{kg} \mathrm{DMI})$ & $1.46^{\mathrm{b}}$ & $1.44^{\mathrm{b}}$ & $0.37^{\mathrm{a}}$ & $0.42^{\mathrm{a}}$ & $0.39^{\mathrm{a}}$ & $0.40^{\mathrm{a}}$ & $0.30^{\mathrm{a}}$ & $0.21^{\mathrm{a}}$ & 0.14 & 0.86 & $<0.001$ & 0.94 \\
\hline
\end{tabular}

Means with the same letter $\left({ }^{\mathrm{abc}}\right)$ are not significantly different $(p>0.05)$; SOP = Star Cow Treatment; $\mathrm{C}=\mathrm{Control}$; $\mathrm{d}=$ day; $\mathrm{d} 0=$ day $0 ; \mathrm{d} 14=$ day $14 ; \mathrm{d} 28=$ day 28; $\mathrm{d} 42=$ day $42 ; \mathrm{Trt}=$ Treatment; $\mathrm{CH}_{4}=$ methane; $\mathrm{CO}_{2}=$ carbon dioxide, $\mathrm{N}_{2} \mathrm{O}=$ nitrous oxide; $\mathrm{NH}_{3}=$ ammonia, $\mathrm{DMI}=$ dry matter intake.

Table 5 reports gaseous emissions standardized for corrected dry matter intake (cDMI) from head chamber DMI and the previous 24-h DMI [18]. No differences for $\mathrm{CH}_{4}, \mathrm{CO}_{2}, \mathrm{~N}_{2} \mathrm{O}$, and $\mathrm{NH}_{3}$ standardized for $\mathrm{CDMI}$ were detected between SOP-treated cows and control cows on respective treatment days. Both SOP-treated cows and control cows showed an increase from day 0 over the treatment period for $\mathrm{N}_{2} \mathrm{O}$.

Table 6 reports gaseous emissions corrected for energy-corrected milk values established from morning milk samples yield, fat percent, and protein percent. No differences for $\mathrm{CH}_{4}, \mathrm{CO}_{2}, \mathrm{~N}_{2} \mathrm{O}$, and $\mathrm{NH}_{3}$ standardized for ECM were detected between SOP-treated cows and control cows on respective treatment days. Both SOP-treated cows and control cows showed an increase from day 0 over the treatment period for $\mathrm{N}_{2} \mathrm{O}$. 
Table 5. Gaseous emissions corrected for corrected dry matter intake (cDMI) from head chambers and the previous 24-h DMI for control and treatment groups $(n=10)$ on days $0,14,28$, and 42 with least square means, pooled standard errors (SEM), and $p$-values. Emission measurements reported are on a per cow basis in either $\mathrm{mg}$ or $\mathrm{g} / \mathrm{h} / \mathrm{kg}$ cDMI. Corrected DMI was determined by the following equation: CDMI $(\mathrm{kg})=0.25 \times$ DMI (previous days feed $(\mathrm{kg}))+0.75 \times \mathrm{DMI}($ in head chamber $(\mathrm{kg}))[18]$.

\begin{tabular}{|c|c|c|c|c|c|c|c|c|c|c|c|c|}
\hline \multirow{3}{*}{ Trait } & \multicolumn{8}{|c|}{ LSM } & \multirow{3}{*}{ SEM } & \multicolumn{3}{|c|}{$p$-Value } \\
\hline & $\mathrm{C}$ & SOP & $\mathrm{C}$ & SOP & $\mathrm{C}$ & SOP & $\mathrm{C}$ & SOP & & \multirow{2}{*}{ Trt } & \multirow{2}{*}{ Day } & \multirow{2}{*}{ Trt:Day } \\
\hline & \multicolumn{2}{|c|}{ do } & \multicolumn{2}{|c|}{ d14 } & \multicolumn{2}{|c|}{$\mathrm{d} 28$} & \multicolumn{2}{|c|}{$\mathrm{d} 42$} & & & & \\
\hline $\mathrm{CH}_{4}(\mathrm{~g} / \mathrm{h} / \mathrm{kg} \mathrm{cDMI})$ & $1.13^{\mathrm{ab}}$ & $0.97^{\mathrm{ab}}$ & $1.11^{\mathrm{b}}$ & $1.08^{\mathrm{b}}$ & $1.04^{\mathrm{ab}}$ & $1.04^{\mathrm{ab}}$ & $0.94^{\mathrm{ab}}$ & $0.85^{\mathrm{a}}$ & 0.06 & 0.15 & $<0.01$ & 0.28 \\
\hline $\mathrm{CO}_{2}(\mathrm{~g} / \mathrm{h} / \mathrm{kg} \mathrm{cDMI})$ & $32.95^{\mathrm{ab}}$ & $29.47^{\mathrm{ab}}$ & $31.00^{\mathrm{ab}}$ & $31.84^{\mathrm{b}}$ & $28.71^{\mathrm{ab}}$ & $30.79^{\mathrm{ab}}$ & $25.71^{\mathrm{ab}}$ & $24.90^{\mathrm{a}}$ & 1.69 & 0.79 & $<0.01$ & 0.18 \\
\hline $\mathrm{N}_{2} \mathrm{O}(\mathrm{mg} / \mathrm{h} / \mathrm{kg}$ cDMI $)$ & $0.53^{\mathrm{a}}$ & $0.48^{\mathrm{a}}$ & $0.80^{\mathrm{ab}}$ & $0.91^{b c}$ & $1.13^{\mathrm{bc}}$ & $1.23^{\mathrm{c}}$ & $1.18^{\mathrm{c}}$ & $1.23^{c}$ & 0.09 & 0.36 & $<0.001$ & 0.71 \\
\hline $\mathrm{NH}_{3}(\mathrm{mg} / \mathrm{h} / \mathrm{kg}$ cDMI $)$ & $0.86^{\mathrm{b}}$ & $0.81^{\mathrm{b}}$ & $0.26^{\mathrm{a}}$ & $0.25^{\mathrm{a}}$ & $0.29^{\mathrm{a}}$ & $0.24^{\mathrm{a}}$ & $0.15^{\mathrm{a}}$ & $0.11^{\mathrm{a}}$ & 0.07 & 0.45 & $<0.001$ & 0.98 \\
\hline
\end{tabular}

Means with the same letter $\left.{ }^{\mathrm{abc}}\right)$ are not significantly different $(p>0.05)$; SOP = Star Cow Treatment; $\mathrm{C}=\mathrm{Control}$; $\mathrm{d}=$ day; $\mathrm{d} 0=$ day $0 ; \mathrm{d} 14=$ day $14 ; \mathrm{d} 28=$ day $28 ; \mathrm{d} 42$ = day $42 ; \operatorname{Trt}=$ Treatment; $\mathrm{CH}_{4}=$ methane; $\mathrm{CO}_{2}=$ carbon dioxide, $\mathrm{N}_{2} \mathrm{O}=$ nitrous oxide; $\mathrm{NH}_{3}=$ ammonia, $\mathrm{DMI}=$ dry matter intake.

Table 6. Gaseous emissions corrected for morning milking's energy-corrected milk values from head chambers for control and treatment groups $(n=10)$ on days $0,14,28$, and 42 with least square means, pooled standard errors (SEM), and $p$-values. Emission measurements reported are on a per cow basis in either $\mathrm{mg}$ or $\mathrm{g} / \mathrm{h} / \mathrm{kg}$ ECM. Energy-corrected milk was established by the following equation: $(0.327 \times$ Milk Yield $(\mathrm{kg}))+(12.95 \times$ Fat $(\mathrm{kg}))+(7.2 \times$ Protein $(\mathrm{kg}))[17]$.

\begin{tabular}{|c|c|c|c|c|c|c|c|c|c|c|c|c|}
\hline \multirow{3}{*}{ Trait } & \multicolumn{8}{|c|}{ LSM } & \multirow{3}{*}{ SEM } & \multicolumn{3}{|c|}{$p$-Value } \\
\hline & $\mathrm{C}$ & SOP & $\mathrm{C}$ & SOP & $\mathrm{C}$ & SOP & $\mathrm{C}$ & SOP & & \multirow{2}{*}{ Trt } & \multirow{2}{*}{ Day } & \multirow{2}{*}{ Trt:Day } \\
\hline & \multicolumn{2}{|c|}{ do } & \multicolumn{2}{|c|}{ d14 } & \multicolumn{2}{|c|}{ d28 } & \multicolumn{2}{|c|}{$\mathrm{d} 42$} & & & & \\
\hline $\mathrm{CH}_{4}(\mathrm{~g} / \mathrm{h} / \mathrm{kg} \mathrm{ECM})$ & 1.43 & 1.07 & 1.32 & 1.13 & 1.37 & 1.19 & 1.08 & 1.03 & 0.12 & 0.11 & 0.021 & 0.096 \\
\hline $\mathrm{CO}_{2}(\mathrm{~g} / \mathrm{h} / \mathrm{kg} \mathrm{ECM})$ & 41.47 & 32.26 & 36.86 & 33.23 & 37.86 & 35.11 & 29.28 & 29.90 & 3.55 & 0.26 & 0.020 & 0.051 \\
\hline $\mathrm{N}_{2} \mathrm{O}(\mathrm{mg} / \mathrm{h} / \mathrm{kg}$ ECM $)$ & $0.69^{\mathrm{a}}$ & $0.54^{\mathrm{a}}$ & $0.99^{\mathrm{abc}}$ & $0.94^{\mathrm{ab}}$ & $1.46^{\mathrm{c}}$ & $1.40^{\mathrm{bc}}$ & $1.45^{\mathrm{bc}}$ & $1.39^{b c}$ & 0.14 & 0.44 & $<0.001$ & 0.96 \\
\hline $\mathrm{NH}_{3}(\mathrm{mg} / \mathrm{h} / \mathrm{kg} \mathrm{ECM})$ & $1.12^{\mathrm{b}}$ & $1.02^{\mathrm{b}}$ & $0.33^{\mathrm{a}}$ & $0.29^{\mathrm{a}}$ & $0.27^{\mathrm{a}}$ & $0.24^{\mathrm{a}}$ & $0.09^{\mathrm{a}}$ & $0.05^{\mathrm{a}}$ & 0.08 & 0.30 & $<0.001$ & 0.98 \\
\hline
\end{tabular}

Means with the same letter $\left({ }^{\mathrm{abc}}\right)$ are not significantly different $(p>0.05)$; SOP $=$ Star Cow Treatment; $\mathrm{C}=$ Control; $\mathrm{d}=$ day; $\mathrm{d} 0=$ day $0 ; \mathrm{d} 14=$ day $14 ; \mathrm{d} 28=$ day $28 ; \mathrm{d} 42=$ day $42 ; \operatorname{Trt}=$ Treatment; $\mathrm{CH}_{4}=$ methane; $\mathrm{CO}_{2}=$ carbon dioxide, $\mathrm{N}_{2} \mathrm{O}=$ nitrous oxide; $\mathrm{NH}_{3}=$ ammonia, $\mathrm{ECM}=$ energy-corrected milk.

\subsection{Milk Parameters and Intake}

The cows enrolled on trial were mid to late lactation (approximately $153 \pm 17$ days in milk). Over the 42-day treatment period milk yield, ECM, $\mathrm{kg}$ of milk fat, milk fat \%, $\mathrm{kg}$ of milk protein, milk protein \%, MUN, dry matter intake from $12 \mathrm{~h}$ in head chambers (DMI HC), and average DMI consumed in Calan gate pens outside of head chambers for each 14-day study period (DMI AVG) were not significantly different for the treatment by day interaction (Table 7). Day is representative of the average over the 14-day study period for milk yield, ECM, milk fat \%, milk protein \%, MUN, and DMI AVG. There was one missing data point for milk component analysis for a milk sample on day 0 during the morning milking. Data for milk yield, and DMI were complete.

No significant variations were observed within or between groups for DMI HC or for DMI AVG (Table 7). There was no difference between the control and SOP-treated cows on respective test days for $\%$ milk protein. Within the groups, the SOP treatment resulted in a significant increase in \% milk protein, with higher $\%$ protein levels throughout the study period $(+4.9 \%$ from day 0 to day $14(p=0.036)$ and $+6.5 \%$ from day 0 to day $42(p=0.002$; Table 7$)$. No changes were detected in the $\%$ milk protein within the control. However, the control and SOP-treated cows showed similar results for kg of milk fat and $\mathrm{kg}$ of milk protein produced per day (Table 7). 
Table 7. Least square means (LSM), pooled standard errors (SEM), and $p$-values for the control (C) and treated (SOP) groups on study days for milk yield, ECM, $\mathrm{kg}$ milk fat, milk fat \%, $\mathrm{kg}$ milk protein, and milk protein \%, milk urea nitrogen (MUN), and dry matter intake in the head chambers (DMI HC) and DMI averaged over the 14 day period (DMI AVG).

\begin{tabular}{|c|c|c|c|c|c|c|c|c|c|c|c|c|}
\hline \multirow{3}{*}{ Trait } & \multicolumn{8}{|c|}{ LSM } & \multirow{3}{*}{ SEM } & \multicolumn{3}{|c|}{$p$-Value } \\
\hline & $\mathrm{C}$ & SOP & $\mathrm{C}$ & SOP & $\mathrm{C}$ & SOP & $\mathrm{C}$ & SOP & & \multirow{2}{*}{$\operatorname{Tr} t$} & \multirow{2}{*}{ Day } & \multirow{2}{*}{ Trt:Day } \\
\hline & \multicolumn{2}{|c|}{ do } & \multicolumn{2}{|c|}{ d14 } & \multicolumn{2}{|c|}{ d28 } & \multicolumn{2}{|c|}{ d42 } & & & & \\
\hline Milk yield (kg/day) & 35.8 & 35.4 & 34.1 & 36.2 & 34.8 & 34.0 & 35.6 & 34.4 & 0.94 & 0.92 & 0.51 & 0.16 \\
\hline ECM (kg/day) & 38.8 & 39.8 & 37.4 & 39.9 & 38.7 & 38.5 & 39.0 & 39.0 & 1.19 & 0.54 & 0.87 & 0.38 \\
\hline Fat (kg/day) & 1.43 & 1.59 & 1.42 & 1.52 & 1.46 & 1.52 & 1.51 & 1.42 & 0.06 & 0.37 & 0.71 & 0.047 \\
\hline Milk Fat (\%) & 4.13 & 4.40 & 4.17 & 4.22 & 4.36 & 4.32 & 4.19 & 4.23 & 0.14 & 0.46 & 0.17 & 0.68 \\
\hline Protein (kg/day) & 1.08 & 1.12 & 1.09 & 1.16 & 1.09 & 1.16 & 1.15 & 1.11 & 0.04 & 0.41 & 0.37 & 0.004 \\
\hline Protein $(\%)$ & $3.12^{\mathrm{ab}}$ & $3.08^{\mathrm{a}}$ & $3.22^{\mathrm{ab}}$ & $3.23^{\mathrm{b}}$ & $3.27^{\mathrm{ab}}$ & $3.27^{\mathrm{b}}$ & $3.18^{\mathrm{ab}}$ & $3.28^{\mathrm{b}}$ & 0.06 & 0.66 & $<0.001$ & 0.21 \\
\hline MUN (mg/100 mL) & $12.68^{b}$ & $13.41^{b}$ & $8.64^{\mathrm{a}}$ & $8.26^{\mathrm{a}}$ & $12.11^{\mathrm{b}}$ & $12.17^{\mathrm{b}}$ & $9.20^{\mathrm{a}}$ & $8.63^{\mathrm{a}}$ & 0.55 & 0.93 & $<0.01$ & 0.38 \\
\hline DMI HC $(\mathrm{kg} / 12 \mathrm{~h})$ & $12.50^{\mathrm{a}}$ & $12.82^{\mathrm{ab}}$ & $15.11^{\mathrm{ab}}$ & $13.96^{\mathrm{ab}}$ & $16.82^{b}$ & $15.91^{\mathrm{ab}}$ & $17.29^{\mathrm{ab}}$ & $15.26^{\mathrm{ab}}$ & 1.10 & 0.36 & $<0.01$ & 0.20 \\
\hline DMI AVG (kg/day) & 24.54 & 25.29 & 24.24 & 24.91 & 24.77 & 25.50 & 26.22 & 26.88 & 0.79 & 0.38 & $<0.001$ & 0.99 \\
\hline
\end{tabular}

Means with the same letter $\left.{ }^{(\mathrm{abc}}\right)$ are not significantly different $(p>0.05)$; SOP = STAR COW treatment; $\mathrm{C}=$ control; $\mathrm{d}=$ day; $\mathrm{d} 0$ = day $0 ; \mathrm{d} 14=$ day $14 ; \mathrm{d} 28$ = day $28 ; \mathrm{d} 42$ = day 42 , Trt = treatment; $\mathrm{ECM}$ = energy-corrected milk; $\mathrm{MUN}=$ milk urea nitrogen .

\section{Discussion}

The use of feed additives to mitigate enteric emissions has received growing attention in recent years since feed additives have the potential to satisfy regulations requiring the dairy sector to reduce its environmental footprint. The present study focused on the possible effects of the commercial feed additive, SOP STAR COW, on enteric emissions and dairy cattle performance.

\subsection{Effects on Enteric Emissions}

There were no pairwise comparison differences detected for any measured parameter between SOP treatment and controls on respective treatment days. There was a day effect showing a reduction in uncorrected $\mathrm{CH}_{4}$ emissions and an increase in milk protein within the SOP-treated group over time, which was not measured in the control group. As control and SOP-treated cows did not show significantly different data on respective test days, the efficacy of using SOP STAR COW as an effective means of reducing enteric $\mathrm{CH}_{4}$ could not be completely validated.

Correcting emissions for DMI in the $\mathrm{HC}$ can be problematic as some animals tend to consume less while in the head chambers than they normally would. This can be seen in Table 7, where there is minimal numeric differences in the average DMI of the animals; however, when in the HC, the SOP-treated animals-after day 0 - were consistently eating between 1 to $2 \mathrm{~kg}$ less feed on a dry matter basis than control cows. While the difference in DMI in the HC was not significant, this can have an effect on standardizing emissions for DMI. Additionally, not all of the $\mathrm{CH}_{4}$ being measured in the HC is attributable to the feed being consumed in the HC. Van Lingen et al. (2017) showed that

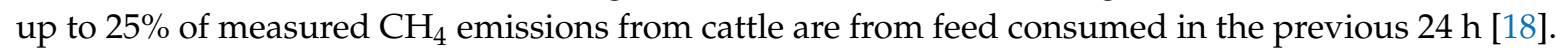
A respiratory chamber study using sheep found that approximately $50 \%$ of $\mathrm{CH}_{4}$ emissions could be attributed to the previous 48 hours' DMI [22]. Further research is needed to establish a more precise model for a DMI correction specific for dairy cattle in head chambers. However, Equation 3, used in this study, helps account for some of the variation in intake while in the HCs and likely gives a more accurate representation of standardized $\mathrm{CH}_{4}$ emissions than just using the HC DMI correction.

Some of STAR COW's components, such as bentonite, tannins, and yeast have previously been shown to individually reduce enteric emissions. Bentonite clay was toxic to some protozoa as it interfered with cilia motion and this has been shown in vitro, when applied at $10 \%$ in the feed, to cause an increase in bacterial populations compared with control samples, as well as a reduction in $\mathrm{NH}_{3}$ production due to its ability to bind $\mathrm{NH}_{3}$ [23]. Wallace and Newbold (1991), utilizing a Rusitec in vitro design, and Abdullah et al. (1995), using sheep in an in vivo experiment, found an inhibitory effect of bentonite on holotrich protozoa [23,24]. Abdullah et al. (1995) additionally found that a $2 \%$ DMI supplementation of sodium bentonite increased the entodinia protozoal population [24]. 
A large portion of the methanogen population have an endosymbiotic relationship with protozoa, with holotrichs and entodinia supporting up to 526 and 96 methanogens internally. This helps explain why defaunation, in some cases, can result in $\mathrm{CH}_{4}$ mitigation [25]. However, it is unlikely that the small quantity of bentonite in the SOP dosage would have this effect on the rumen. It is possible that a higher quantity of bentonite may be more effective at mitigating $\mathrm{CH}_{4}$ emissions.

Research has determined two possible mechanisms to achieve a reduction in enteric $\mathrm{CH}_{4}$ emissions in cattle after tannin supplementation, including (1) decreasing hydrogen production through a reduction in fiber digestibility, and (2) the inhibition of methanogens [12]. Previous research on tannins as feed additives focused on their ability to improve nutrient utilization efficiency, in particular nitrogen $(\mathrm{N})$, and reduce nutrient loss via $\mathrm{NH}_{3}$ emissions into the environment [26,27]. A recent in vitro study found a 20 to $27 \%$ decrease in $\mathrm{CH}_{4}$ emissions, as well as a decrease in the total VFA and the acetate to propionate ratio, by injecting both hydrolyzed (HT) and condensed tannins (CT) at a 1:1 ratio into the rumen volume [28]. Reducing total VFA content is not ideal as this indicates a reduction in overall rumen fermentation, which would reduce feed efficiency and production performance. However, these trials were including tannins at a much higher dose than the current study and in vitro trials are not always representative of the effect that will be seen in vivo, largely due to the lack of time microbial populations have to adjust, and are more indicative of short-term results. Further in vivo research is needed to determine if a higher dose of SOP can be more effective at mitigating $\mathrm{CH}_{4}$ emissions and if VFA concentrations in the rumen or DMI are altered.

Similarly, significant decreases in the molar \% of acetate, acetate to propionate ratio, and crude protein digestibility were noted when $\mathrm{CT}$ were fed to Angus cattle at $2 \% \mathrm{DM}$; however, no differences in $\mathrm{CH}_{4}$ or BW were seen [29]. Usually, a decrease in acetate to propionate concentrations is consistent with other methods of decreasing enteric $\mathrm{CH}_{4}$ emissions as it is likely a result of decreased levels of hydrogen being available as a substrate for methanogens in the rumen.

The SOP treatment used low quantities of material ( $8 \mathrm{~g} /$ animal per day, approx. $0.04 \%$ DM of the complete feed). Other additives, including tannins, usually need to be included at $20 \mathrm{~g} / \mathrm{kg}$ diet DM to have a reliable reduction in $\mathrm{CH}_{4}$ [30]. However, a synergistic effect of the components in SOP has never been researched for $\mathrm{CH}_{4}$ mitigation. Borgonovo et al. (2019) and Peterson et al. (2020) [31,32] found that gypsum processed with SOP's proprietary technology reduced $\mathrm{NH}_{3}$ and $\mathrm{GHG}$ emissions in liquid manure with a much lower dosage of gypsum than reported previously [33]. However, this same effect with low doses was not seen in the current study.

Given that the uncorrected gas emissions results showed a reduction in $\mathrm{CH}_{4}$ over time for SOP-treated cows, it is possible that SOP STAR COW has some $\mathrm{CH}_{4}$ mitigation potential. However, to determine a true reduction potential, this change would also need to be seen when standardized for DMI. Likewise, SOP STAR COW might have better $\mathrm{CH}_{4}$ mitigation responses if fed at higher amounts, as most effective feed additives with similar compounds are fed at a much higher percentage of DMI [28-30].

\subsection{Effects on Milk Production}

SOP STAR COW-treated cows showed similar results to control cows for the treatment by day interaction for all milk parameters and intake data. Within the SOP treatment group, the cows showed an increase in milk protein percent over the course of trial period; however, $\mathrm{kg}$ of milk protein remained similar within the SOP-treated cows over the trial period.

SOP STAR COW contains tannins, which have the ability to bind proteins in the rumen, thus reducing protein degradation by rumen microorganisms and making proteins available for digestion in the small intestine. This likely increased the availability of amino acids (AA) for the animal to absorb from the feed. Previous research on tannins as a feed additive focused on their ability to improve nutrient utilization efficiency, in particular nitrogen (N) [28,29], though these studies did not investigate their ability to reduce enteric emissions. Aguerre et al. (2016) found that feeding CT at $0.45 \%$ of diet DM resulted in an increase in milk protein yield; however, at CT levels higher than $0.45 \%$, milk protein yield and percentage were decreased [29]. While an increase in \% milk protein was seen in the current 
study within the SOP-treated cows over time, there was no difference in $\mathrm{kg}$ of milk protein produced, so synthesis of milk protein remained unchanged.

SOP STAR COW contains deactivated yeast cells, which act as a prebiotic for microbiota in the digestive system. Yeast cultures provide soluble growth factors such as organic acids, B vitamins, and amino acids that stimulate the growth of ruminal bacteria populations that utilize lactate and digest cellulose [34]. The supplementation of diets with yeasts was used to increase the final protein content in the milk, by providing probiotic and prebiotic materials to the ruminal flora. Several studies have confirmed the effect of yeast on milk protein percentage, but these studies used live yeast cultures [35-37]. Both deactivated yeast and CT in SOP STAR COW potentially explain the increased protein percent over time in the milk of SOP-treated cows, while the \% protein in the control cows' milk remained unchanged.

Previous research has shown that supplementing dairy cows with yeast cultures increased DMI and milk yield and decreased the acetate to propionate ratio in the rumen [38,39]. Additionally, yeast supplementation altered the amino acid profile of bacterial protein and the flow of methionine from the rumen to the small intestine, which could potentially increase milk protein synthesis [39]. Further research is needed to determine if SOP increases the post-ruminal flow of methionine in support of milk protein synthesis.

Since tannins and deactivated yeast comprise only $5 \%$ of SOP content, coupled with the small feeding inclusion ( $8 \mathrm{~g} / \mathrm{head} /$ day), the suggested mode of action to increase protein content might be related to an increase and/or a shift in the rumen microbial population.

As recent studies have investigated the role of predominant clusters of ruminal microbes in milk production and $\mathrm{CH}_{4}$ formation [40], further investigations should determine the potential impact of SOP STAR COW on the microbial populations in the rumen as an approach to explain its potential modes of action.

\section{Conclusions}

No differences were detected for enteric emissions, standardized enteric emissions, milk parameters, or intake between control and SOP-treated cows on respective test days. Analyzing the two groups separately, within SOP-treated cows over time, showed a significant reduction in $\mathrm{CH}_{4}$ of $20.4 \%$ from day 14 to day 42 , while the protein $\%$ of the milk was increased $(+4.9 \%$ from day 0 to day 14 and $+6.5 \%$ from day 0 to day 42). Over time, within the control group, there was no reduction in $\mathrm{CH}_{4}$ or increase in milk protein. Within the SOP-treated cows, the $\mathrm{kg}$ of milk protein remained similar throughout the duration of the study. Tannins and yeast, present in SOP STAR COW, may be effective compounds that enable a reduction in enteric $\mathrm{CH}_{4}$ emissions, and should be researched further. Future research should investigate the effects of long-term supplementation or higher doses of SOP STAR COW, in order to determine if greater mitigation effects on $\mathrm{CH}_{4}$ emissions and increases in milk production can be established. Increasing pressure from legislation and consumers is being put on the dairy industry to reduce the environmental impact of dairy production, especially as it relates to climate change. Determining feed additives that both reduce emissions and improve the production of lactating dairy cows is both essential for producers to meet current $\mathrm{CH}_{4}$ reduction regulations and is an important step towards a sustainable food system.

Author Contributions: Conceptualization, E.G.R., C.B.P., E.J.D. and F.M.M.; data curation, E.G.R., C.B.P., A.V.C., S.J.W., Y.Z., Y.P. and L.P.; formal analysis, E.G.R. and J.G.F.; Funding acquisition, F.M.M.; investigation, E.G.R., C.B.P., A.V.C., S.J.W. and F.M.M.; methodology, E.G.R., C.B.P. and F.M.M.; project administration, E.G.R., Y.Z. and F.M.M.; writing—original draft, E.G.R. and M.E.C.; writing—review and editing, C.B.P., A.V.C., S.J.W., Y.Z., Y.P., E.J.D., J.G.F., L.P. and F.M.M.; All authors have read and agreed to the published version of the manuscript.

Funding: This study was funded by SOP Srl (SOP Srl, VA, Italy).

Acknowledgments: We kindly thank: Doug Gisi, the manager of the UC Davis Dairy, and his staff for their help and support with this trial, the undergraduate student interns that were instrumental in the day to day work, as well as our sponsors at SOP.

Conflicts of Interest: The authors declare no conflict of interest. 


\section{References}

1. Adesogan, A.T.; Havelaar, A.H.; McKune, S.L.; Eilittä, M.; Dahl, G.E. Animal source foods: Sustainability problem or malnutrition and sustainability solution? Perspective matters. Glob. Food Secur. 2020, 25, 100325. [CrossRef]

2. IPCC. IPCC Emissions from Livestock and Manure Management (Chapter 10); Eggleston, H.S., Buendia, L., Miwa, K., Ngara, T., Tanabe, K., Eds.; IGES: Kanagawa, Japan, 2006; Volume 4.

3. Syakila, A.; Kroeze, C. The global nitrous oxide budget revisited. Greenh. Gas Meas. Manag. 2011, 1, 17-26. [CrossRef]

4. USEPA. Inventory of U.S. Greenhouse Gas Emissions and Sinks: 1990-2015. 2017. Available online: https://www.epa.gov/sites/production/files/2017-02/documents/2017_chapter_5_agriculture.pdf (accessed on 17 June 2020).

5. United States Department of Agriculture Economic Research Service. Available online: https://www.ers. usda.gov/webdocs/DataFiles/48685/milkcowsandprod.xlsx?v=1518.6 (accessed on 17 June 2020).

6. CARB. California Air Resources Board. Short-Lived Climate Pollutant Reduction Strategy. 2017. Available online: https://ww2.arb.ca.gov/sites/default/files/2020-07/final_SLCP_strategy.pdf (accessed on 15 June 2020).

7. Johnson, K.A.; Johnson, D.E. Methane emissions from cattle. J. Anim. Sci. 1995, 73, 2483-2492. [CrossRef] [PubMed]

8. Knight, T.; Ronimus, R.S.; Dey, D.; Tootill, C.; Naylor, G.; Evans, P.; Molano, G.; Smith, A.; Tavendale, M.; Pinares-Patiño, C.; et al. Chloroform decreases rumen methanogenesis and methanogen populations without altering rumen function in cattle. Anim. Feed. Sci. Technol. 2011, 166, 101-112. [CrossRef]

9. Adesogan, T.; Yang, W.; Lee, C.; Gerber, P.J.; Henderson, B.; Tricarico, J.M. Mitigation of methane and nitrous oxide emissions from animal-SPECIAL TOPICS. J. Anim. Sci. 2013, 91, 5045-5069.

10. Hristov, A.N.; Oh, J.; Kindermann, M.; Duval, S.; Giallongo, F.; Frederick, T.W.; Harper, M.T.; Weeks, H.L.; Branco, A.F.; Moate, P.J.; et al. An inhibitor persistently decreased enteric methane emission from dairy cows with no negative effect on milk production. Proc. Natl. Acad. Sci. USA 2015, 112, 10663-10668. [CrossRef] [PubMed]

11. Van Zijderveld, S.; Gerrits, W.; Dijkstra, J.; Newbold, J.; Hulshof, R.; Perdok, H. Persistency of methane mitigation by dietary nitrate supplementation in dairy cows. J. Dairy Sci. 2011, 94, 4028-4038. [CrossRef]

12. Tavendale, M.H.; Meagher, L.P.; Pacheco, D.; Walker, N.; Attwood, G.T.; Sivakumaran, S. Methane production from in vitro rumen incubations with Lotus pedunculatus and Medicago sativa, and effects of extractable condensed tannin fractions on methanogenesis. Anim. Feed. Sci. Technol. 2005, 123, 403-419. [CrossRef]

13. Benchaar, C.; Greathead, H. Essential oils and opportunities to mitigate enteric methane emissions from ruminants. Anim. Feed. Sci. Technol. 2011, 166, 338-355. [CrossRef]

14. Roque, B.M.; Brooke, C.G.; Ladau, J.; Polley, T.; Marsh, L.J.; Najafi, N.; Pandey, P.; Singh, L.; Kinley, R.; Salwen, J.K.; et al. Effect of the macroalgae Asparagopsis taxiformis on methane production and rumen microbiome assemblage. Animal Microbiome 2019, 1, 3. [CrossRef]

15. Luparia, P.; Rota, N.; Poggianella, M.; Bronzo, V. Preliminary results of a feed additive for rumen functionality through in-field monitoring on 7 Italian commercial dairy farms. In Proceedings of the 19th European Society of Veterinary and Comparative Nutrition (ESVCN) Congress, Tulouse, France, 17-19 September 2015.

16. Place, S.; Pan, Y.; Zhao, Y.; Mitloehner, F.M. Construction and operation of a ventilated hood system for measuring greehouse gas and volatile organic compound emissions from cattle. Animals 2011, 1, 433-446. [CrossRef]

17. Dairy Records Management Systems DHI Glossary. Available online: http://www.drms.org/PDF/materials/ glossary.pdf (accessed on 12 December 2019).

18. Van Lingen, H.J.; Edwards, J.E.; Vaidya, J.D.; Van Gastelen, S.; Saccenti, E.; Bogert, B.V.D.; Bannink, A.; Smidt, H.; Plugge, C.M.; Dijkstra, J. Diurnal Dynamics of Gaseous and Dissolved Metabolites and Microbiota Composition in the Bovine Rumen. Front. Microbiol. 2017, 8, 425. [CrossRef]

19. Kuznetsova, A.; Brockhoff, P.B.; Christensen, R.H.B. lemerTest: Tests in Linear Mixed Effects Models. R package version 2.0-30. J. Stat. Softw. 2017, 82, 1-26. [CrossRef]

20. Lenth, R.; Singmann, H.; Love, J.; Buerkner, P.; Herve, M. Emmeans: Estimated Marginal Means, Aka Least-Squares Means; R package version 1.3.2; 2019. Available online: https://CRAN.R-project. org/package=emmeans (accessed on 18 March 2019).

21. Graves, S.; Piepho, H.P.; Selzer, L. MulticompView: Visualizations of Paired Comparisons; R package version 0.1-7. 2017. Available online: https//github.com/rvlenth/emmeans/issues (accessed on 18 March 2019). 
22. Robinson, D.L.; Goopy, J.P.; Donaldson, A.J.; Woodgate, R.T.; Oddy, V.H.; Hegarty, R.S. Sire and liveweight affect feed intake and methane emissions of sheep confined in respiration chambers. Animal 2014, 8, 1935-1944. [CrossRef]

23. Wallace, R.J.; Newbold, C.J. Effects of bentonite on fermentation in the rumen simulation technique (Rusitec) and on rumen ciliate protozoa. J. Agric. Sci. 1991, 116, 163-168. [CrossRef]

24. Abdullah, N.; Hanita, H.; Ho, Y.W.; Kudo, H.; Jalaludin, S.; Ivan, M. The effects of bentonite on rumen protozoal population and rumen fluid characteristics of sheep fed palm kernel cake. Asian Australas. J. Anim. Sci. 1995, 8, 249-254. [CrossRef]

25. Finlay, B.J.; Esteban, G.; Clarke, K.J.; Williams, A.G.; Embley, T.M.; Hirt, R.P. Some rumen ciliates have endosymbiotic methanogens. FEMS Microbiol. Lett. 1994, 117, 157-161. [CrossRef] [PubMed]

26. Dschaak, C.; Williams, C.; Holt, M.; Eun, J.-S.; Young, A.; Min, B. Effects of supplementing condensed tannin extract on intake, digestion, ruminal fermentation, and milk production of lactating dairy cows. J. Dairy Sci. 2011, 94, 2508-2519. [CrossRef] [PubMed]

27. Aguerre, M.; Capozzolo, M.; Lencioni, P.; Cabral, C.; Wattiaux, M. Effect of quebracho-chestnut tannin extracts at 2 dietary crude protein levels on performance, rumen fermentation, and nitrogen partitioning in dairy cows. J. Dairy Sci. 2016, 99, 4476-4486. [CrossRef]

28. Jayanegara, A.; Makkar, H.P.S.; Becker, K. Addition of Purified Tannin Sources and Polyethylene Glycol Treatment on Methane Emission and Rumen Fermentation in Vitro. Media Peternak. 2015, 38, 57-63. [CrossRef]

29. Beauchemin, K.A.; McGinn, S.M.; Martínez, T.F.; McAllister, T.A. Use of condensed tannin extract from quebracho trees to reduce methane emissions from cattle. J. Anim. Sci. 2007, 85, 1990-1996. [CrossRef]

30. Jayanegara, A.; Leiber, F.; Kreuzer, M. Meta-analysis of the relationship between dietary tannin level and methane formation in ruminants from in vivo and in vitro experiments. J. Anim. Physiol. Anim. Nutr. 2011, 96, 365-375. [CrossRef]

31. Borgonovo, F.; Conti, C.; Lovarelli, D.; Ferrante, V.; Guarino, M. Improving the Sustainability of Dairy Slurry by A Commercial Additive Treatment. Sustainability 2019, 11, 4998. [CrossRef]

32. Peterson, C.B.; El-Mashad, H.M.; Zhao, Y.; Pan, Y.; Mitloehner, F.M. Effects of SOP Lagoon Additive on Gaseous Emissions from Stored Liquid Dairy Manure. Sustainability 2020, 12, 1393. [CrossRef]

33. Yang, F.; Li, G.; Shi, H.; Wang, Y. Effects of phosphogypsum and superphosphate on compost maturity and gaseous emissions during kitchen waste composting. Waste Manag. 2015, 36, 70-76. [CrossRef] [PubMed]

34. Callaway, E.; Martin, S. Effects of a Saccharomyces cerevisiae Culture on Ruminal Bacteria that Utilize Lactate and Digest Cellulose. J. Dairy Sci. 1997, 80, 2035-2044. [CrossRef]

35. Moallem, U.; Lehrer, H.; Livshitz, L.; Zachut, M.; Yakoby, S. The effects of live yeast supplementation to dairy cows during the hot season on production, feed efficiency, and digestibility. J. Dairy Sci. 2009, 92, 343-351. [CrossRef] [PubMed]

36. Rossow, H.A.; Riordan, T. Effects of addition of a live yeast product on dairy cattle performance. J. Appl. Anim. Res. 2018, 46, 159-163. [CrossRef]

37. Dias, A.; Freitas, J.; Micai, B.; Azevedo, R.; Greco, L.; Santos, J. Effect of supplemental yeast culture and dietary starch content on rumen fermentation and digestion in dairy cows. J. Dairy Sci. 2018, 101, 201-221. [CrossRef]

38. Erasmus, L.; Botha, P.; Kistner, A. Effect of Yeast Culture Supplement on Production, Rumen Fermentation, and Duodenal Nitrogen Flow in Dairy Cows. J. Dairy Sci. 1992, 75, 3056-3065. [CrossRef]

39. Williams, P.E.; Tait, C.; Innes, G.M.; Newbold, C.J. Effects of the inclusion of yeast culture (Saccharomyces cerevisiae plus growth medium) in the diet of dairy cows on milk yield and forage degradation and fermentation patterns in the rumen of steers. J. Anim. Sci. 1991, 69, 3016-3026. [CrossRef]

40. Wallace, R.J.; Sasson, G.; Garnsworthy, P.C.; Tapio, I.; Gregson, E.; Bani, P.; Huhtanen, P.; Bayat, A.; Strozzi, F.; Biscarini, F.; et al. A heritable subset of the core rumen microbiome dictates dairy cow productivity and emissions. Sci. Adv. 2019, 5, eaav8391. [CrossRef]

Publisher's Note: MDPI stays neutral with regard to jurisdictional claims in published maps and institutional affiliations. 